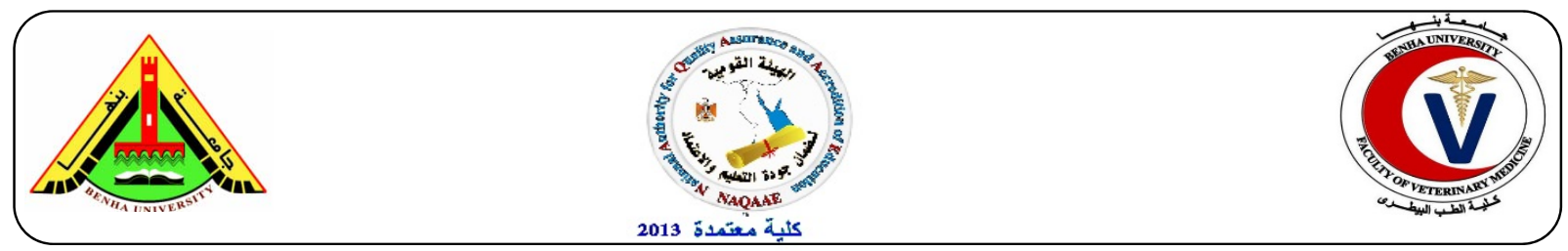

\title{
Alterations in biochemical parameters and hepatic ultrasonography with reference to oxidant injury in ketotic dairy cows
}

\author{
Ghanem, M.M. ${ }^{1 *}$, Mahmoud, M.E. ${ }^{2}$, Abd El-Raof, Y.M. ${ }^{1,}$ El-Attar, H.M. ${ }^{1}$ \\ ${ }^{1}$ Animal Medicine Department, Faculty of Vet. Medicine, Benha University, \\ ${ }^{2}$ Animal Medicine Dept., Faculty of Veterinary Medicine, Aswan University. \\ Corresponding author: mohamed.ghanem@fvtm.bu.edu.eg
}

\begin{abstract}
A B S T R A C T
This study aimed to evaluate the clinical, biochemical and hepatic ultrasonographic changes in ketotic dairy cows. For that purpose, we examined 42 lactating Holstein- Friesian cows with ages from 3-10 years old during the post parturient period (up to 6 weeks postpartum). The cows were classified into control healthy $(\mathrm{C}=20)$, subclinical ketotic cows $(\mathrm{SCK}=17)$ and clinical ketotic cows $(\mathrm{CK}=5)$. Clinically, anorexia and reduction in milk yield were observed in $\mathrm{CK}$ cows. The ruminal movements showed a significant depression $(P<0.05)$ in $\mathrm{CK}$ than SCK and control. The serum glucose, insulin and cortisol showed a highly significant decrease $(P<0.001)$ in $\mathrm{CK}$ and SCK than control. The serum NEFA and BHBA showed a highly significant increase $(P<0.001)$ in $\mathrm{CK}$ and SCK than control. Serum cholesterol and HDL levels showed a significant $(P<0.01)$ decrease in SCK and CK cows than control. Serum triglycerides (TG) and very low density lipoprotein (VLDL) were significantly decreased $(P<0.01)$ in CK than control. The serum activity of AST, ALT and GGT were significantly increased $(P<0.05)$ in $\mathrm{CK}$ cows than control. Serum $\mathrm{Ca}$ and $\mathrm{P}$ levels were significantly decreased $(P<0.05)$ in CK cows than SCK and control. Regarding the oxidative stress biomarkers, serum level of malondialdehyde (MDA) showed a highly significant $(P<0.001)$ increase in CK cows than SCK and control whereas, serum superoxide dismutase (SOD) level was significantly decreased $(P<0.05)$ in CK cows than control. Hepatic ultrasonography of ketotic cows revealed varying degrees of fatty infiltration (focal and diffuse fatty infiltration) appeared as increased hepatic echogenicity with a blurring of hepatic blood vessels. It is concluded that ketosis induced clinical, biochemical and ultrasonographical changes in lactating cows. Oxidant injury could be implicated in the pathogenesis of the disease.
\end{abstract}

KEYWORDS: Anti-oxidant, biochemical, ketosis, subclinical ketosis, ultrasonography

(http://www.bvmj.bu.edu.eg)

(BVMJ-31(2): 231-240, 2016)

\section{INTRODUCTION}

Ketosis has been recognized as one of the main important metabolic disorders in dairy cows. It is caused by impaired metabolism of carbohydrate and volatile fatty acids that lead to excessive production of ketone bodies: acetoacetic acid, BHBA and their decarboxylation product such as acetone and isopropanol (Radostits et al., 2007). Ketosis can be classified into SCK and CK. CK is characterized by an increase in blood, urine, or milk ketone bodies in conjunction with other visible signs, such as inappetence, obvious rapid weight loss, and dry manure, CK has different clinical forms mainly digestive and nervous forms (Rosenberger and Rinds, 2006). Ketosis in dairy cows is associated with lipolysis due to negative energy balance (NEB) which leads to fatty liver infiltration. When fat infiltrates the liver, hepatocyte degeneration involves cell membrane damage and hepatocyte destruction, and the levels of enzymes that indicate liver injury are generally increased (Lubojacka et al., 2005 and Đjoković et al., 2016). During ketosis, the large amount of NEFAs emerged from fat mobilization of dairy ketotic cows may induce oxygen radical such as reactive oxygen species (ROS), which can initiate oxidative stress (Schönfeld and Wojtczak, 2008). MDA is one of the final products of polyunsaturated fatty acid peroxidation which is caused by increasing level of ROS and is commonly known as a marker of oxidative damage. Oxidative stress occurs when an imbalance happens between oxidative system and antioxidative system, which can cause cellular damaged (Abuelo et al., 2013). Ultrasonographic examination of hepatic lipidosis in cows revealed an increased coarseness of echoes, increased echogenicity of the liver parenchyma near the abdominal wall, weakening of echo as distance 
increases from abdominal wall and poor or no visualization of hepatic vessel (Braun et al., 1996). Because ketosis represents a major economic problem in dairy farms due to the adverse effect on milk production, this study aimed to monitor alterations in the clinical, biochemical and oxidant/ antioxidant parameters in ketotic lactating cows. In addition, the hepatic changes were evaluated by ultrasonography.

\section{MATERIAL AND METHODS}

\subsection{Animals and experimental design}

This study was carried out on 42 lactating Holstein- Friesian cows of different ages 3- 10 years old during post-parturient period (up to 6 weeks postpartum) with average of daily milk production $(28.47 \pm 2.96) \mathrm{kg} /$ day which varies from $13-50 \mathrm{~kg} /$ day, These cows were located in eight dairy farms in four governorates (Qalubia, Dakhalia, Menofia and Ismailia governorates), according to the clinical signs and the colorimetric measurement of the serum BHBA levels (Duffield, 2000) at a cut-off point of serum BHBA $\geq 1.200 \mathrm{mmol} / \mathrm{L}$, these cows were classified into3groups. Group 1 included 20 cows (control) that are apparently healthy by clinical examination and negative with colorimetric enzymatic method. Group 2 included 17 cows that are apparently healthy by clinical examination and positive with colorimetric enzymatic method (SCK group). Group 3 included 5 cows that are clinically diseased (CK) and positive with colorimetric enzymatic method.

\subsection{Ration.}

Cows were fed daily on diet consisting of $25 \mathrm{Kg}$ darawa or $25 \mathrm{Kg}$ barseem, $12-18 \mathrm{~kg}$. corn silage, 4 $\mathrm{Kg}$. hay straw and $12 \mathrm{~kg}-18 \mathrm{~kg}$ concentrates with (16\% protein) per animal.

\subsection{Management System.}

All cows were kept in a free-stall barn and were kept under the same environmental condition.

\subsection{Samples.}

The blood Samples: the blood samples were collected from jugular vein of all cows during postpartum period during the early morning (Kelly, 1984). Serum samples were separated and used for biochemical analysis.

\subsection{Clinical examination.}

Determination of body temperature, pulse, respiratory rates and ruminal movement, as well as examination of mucous membranes was conducted according to Radostits et al. (2007).

\subsection{Biochemical analysis.}

The clear non -hemolyzed serum were used for the quantitative determination of glucose, NEFA, BHBA, cortisol, insulin, cholesterol, TG, HDL, low Density lipoproteins (LDL), albumin, total protein, urea, creatinine, $\mathrm{Ca}, \mathrm{P}, \mathrm{AST}$, ALT, GGT, MDA and SOD by using commercial kits.

\subsection{Hepatic ultrasonography examination.}

The hepatic ultrasonography was performed as previously described (Braun et al., 1996). In brief, the hair was clipped on right side imaged on the right lateral abdomen below the diaphragmatic attachment from the 5 th to $12^{\text {th }}$ intercostal space and just caudal to the 13th rib. Gel was applied and B-mode ultrasonography performed using greyscale equipment (Imago, France) with a $3.5 \mathrm{MHz}$ convex transducer.

\subsection{Statistical analysis.}

All statistical analysis was performed using the Sigma Stat 3.1, statistical software (SPSS Inc., Chicago, IL, USA). Difference between groups was analyzed by using one way analysis of variance (ANOVA) and post hock turkey test. Results were presented as means $(\mathrm{M}) \pm$ standard errors (S.E.) The significance was determined when $P<0.05$.

\section{RESULTS}

\subsection{Clinical findings}

As shown in Table1, the complete anorexia was observed in one CK cows. While, partial anorexia (refuse to eat concentrate) was observed in four CK cows. Acetone odor in breath was detected only in one CK cow. Scanty firm feces were observed in three CK cows. A reduction in milk yield was observed in all CK cows. The average of daily milk production in healthy cows was $28.47 \pm 2.96$ $\mathrm{kg} /$ day, while SCK showed $5.6 \%$ reduction in milk production and CK cows showed $9.1 \%$ reduction in milk production. The body temperature, respiratory and pulse rate of $\mathrm{CK}$ did not show significant changes compared to control. The ruminal movements of $\mathrm{CK}$ cows showed a significant decrease $(P<0.05)$ than SCK and control. The mucous membrane of $\mathrm{CK}$ and SCK cows was pale compared with rosy red color of control (Table 2).

\subsection{Biochemical analysis.}

As demonstrated in Table 3, the serum glucose levels showed a highly significant $(P<0.001)$ decrease in CK cows and SCK than control, serum glucose levels showed a significant $(P<0.05)$ 
decrease in CK cows than SCK. Serum NEFA and BHBA showed a highly significant $(P<0.001)$ increase in SCK and CK cows than control, serum NEFA showed a significant $(P<0.05)$ increase in CK cows than SCK, serum BHBA showed highly significant $(P<0.001)$ increase in $C K$ cows than SCK Regarding the hormonal profile, serum insulin and cortisol levels showed a highly significant $(P<0.001)$ decrease in $\mathrm{CK}$ cows and SCK than control, serum insulin levels showed a significant $(P<0.05)$ decrease in CK cows than SCK. Regarding the lipid profile, serum TG levels showed a significant $(P<0.05)$ decrease in $\mathrm{CK}$ cows than SCK and control, serum cholesterol levels showed a significant $(P<0.01)$ decrease in SCK and CK cows than control. Serum HDL levels showed a significant $(P<0.01)$ decrease in $\mathrm{CK}$ and SCK than control. Serum LDL levels showed a significant $(P<0.01)$ decrease in SCK than control. Serum VLDL levels showed a significant $(P<0.05)$ decrease in CK cows than SCK and control. Regarding the protein profile, serum TP and globulin levels showed a significant $(P<0.05)$ decrease in CK cows than SCK. Serum albumin levels showed insignificant change in $\mathrm{CK}$ cows

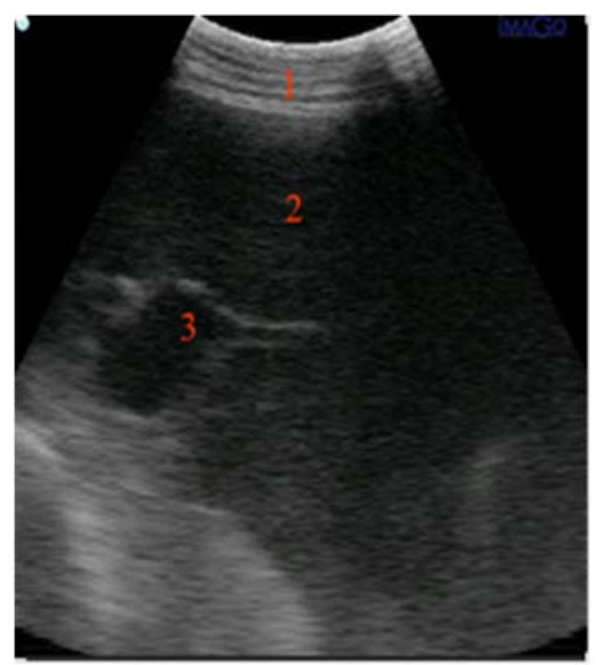

Figure 1 Hepatic ultrasonograms in control healthy cows showing normal gray echogenicity 1. Abdominal wall 2. Liver parenchyma 3. Portal vein. (Imaged through 11th ICS by convex transducer 3.5 MHz Imago). than SCK and control. Regarding the enzymatic functions, serum AST, GGT and ALT activity showed a significant $(P<0.05)$ increase in $\mathrm{CK}$ cows than control, serum AST showed a significant $(P<0.01)$ increase in CK cows than SCK. Regarding the kidney functions, Serum urea levels showed a significant $(P<0.05)$ decrease in SCK and CK cows than control. Serum creatinine levels showed insignificant changes in CK cows and SCK than control. Regarding the minerals serum levels, Serum $\mathrm{Ca}$ and $\mathrm{P}$ levels were significantly decreased $(P<0.05)$ in CK than SCK and control. Regarding the oxidative stress biomarkers, serum MDA levels showed a highly significant $(P<0.001)$ increase in CK cows than SCK and control. serum SOD levels showed a significant $(P<0.05)$ decrease in CK cows than control.

\subsection{Hepatic ultrasonographic changes in ketotic cows.}

Ultrasonographic examination of liver in ketotic showed varying degrees of fatty infiltration (focal and diffuse fatty infiltration) which result in increased hepatic echogenicity with blurring of hepatic blood vessels (Figure 2)

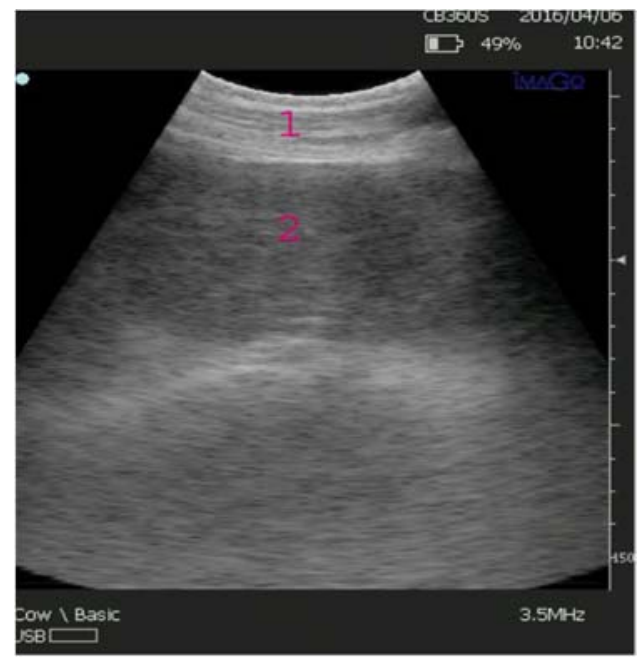

Figure 2 Hepatic ultrasonogram in ketotic cows 1 . Abdominal wall 2. Fatty infiltration (increased echogenicity, blurring of hepatic blood vessels) (Imaged through 11th ICS by convex transducer 3.5 $\mathrm{MHz}$ Imago)

Table1 Clinical findings in clinical ketotic cows

\begin{tabular}{ccc}
\hline No. of affected cows & Clinical finding & Percentage \\
\hline 1 & Complete anorexia & $20 \%$ \\
4 & Selective feeding (partial anorexia) & $80 \%$ \\
1 & Acetone odor in breath & $20 \%$ \\
3 & Scanty firm feces & $60 \%$ \\
5 & Reduction in milk yield & $100 \%$ \\
\hline
\end{tabular}


Table 2 Clinical parameters in control, SCK and CK cows

\begin{tabular}{lccc}
\hline Parameter & $\begin{array}{c}\text { Control } \\
(\mathrm{n}=20)\end{array}$ & $\begin{array}{c}\text { SCK cows } \\
(\mathrm{n}=17)\end{array}$ & $\begin{array}{c}\text { CK cows } \\
(\mathrm{n}=5)\end{array}$ \\
\hline Body temperature $\left({ }^{\circ} \mathrm{C}\right)$ & $38.7 \pm 0.11^{\mathrm{a}}$ & $38.6 \pm 0.06^{\mathrm{a}}$ & $38.8 \pm .07^{\mathrm{a}}$ \\
Respiratory rate/minute & $18.5 \pm 036^{\mathrm{a}}$ & $17.7 \pm 0.35^{\mathrm{a}}$ & $18.85 \pm .26^{\mathrm{a}}$ \\
Pulse rate/minute & $57.8 \pm 2.1^{\mathrm{a}}$ & $58.2 \pm 1.89^{\mathrm{a}}$ & $60.1 \pm 1.6^{\mathrm{a}}$ \\
Rumen contractions $(2$ minute $)$ & $2.5 \pm 0.1^{\mathrm{a}}$ & $2.47 \pm 0.1^{\mathrm{ab}}$ & $1.6 \pm .24^{\mathrm{b}}$ \\
\hline \multicolumn{2}{c}{ Means with different superscripts indicate significant difference at $P<0.05$}
\end{tabular}

Table 3 Biochemical changes in control, SCK and CK cows

\begin{tabular}{|c|c|c|c|}
\hline Parameter & Control $(\mathrm{n}=20)$ & SCK cows $(n=17)$ & CK $\operatorname{cows}(n=5)$ \\
\hline Glucose (mg/dl) & $50.9 \pm 2.28^{\mathrm{a}}$ & $36.4 \pm 1.21^{\mathrm{b}}$ & $30.08 \pm 1^{\mathrm{c}}$ \\
\hline NEFA (mmol/l) & $.176 \pm .027^{\mathrm{c}}$ & $1.05 \pm .05^{\mathrm{b}}$ & $1.298 \pm .13^{\mathrm{a}}$ \\
\hline BHBA $(\mathrm{mmol} / \mathrm{l})$ & $.501 \pm .02^{\mathrm{c}}$ & $1.75 \pm .093^{\mathrm{b}}$ & $3.02 \pm .07^{\mathrm{a}}$ \\
\hline Insulin (uIU/ml) & $27.6 \pm 1.19^{\mathrm{a}}$ & $16.52 \pm .91^{\mathrm{b}}$ & $11.84 \pm .7^{\mathrm{c}}$ \\
\hline Cortisol (nmol/l) & $29.7 \pm 2.4^{\mathrm{a}}$ & $16.6 \pm 1.08^{b}$ & $9.9 \pm 1.4^{\mathrm{c}}$ \\
\hline $\mathrm{TG}(\mathrm{mg} / \mathrm{dl})$ & $184.06 \pm 10.6^{\mathrm{a}}$ & $169.4 \pm 6.9^{\mathrm{a}}$ & $126.6 \pm 13.97^{b}$ \\
\hline Cholesterol (mg/dl) & $170.6 \pm 8.9^{\mathrm{a}}$ & $122.6 \pm 6.04^{b}$ & $114.9 \pm 7.9^{\mathrm{b}}$ \\
\hline $\mathrm{HDL}(\mathrm{mg} / \mathrm{dl})$ & $60.4 \pm 3.8^{\mathrm{a}}$ & $44.8 \pm 2.9^{\mathrm{b}}$ & $34.81 \pm 2.14^{b}$ \\
\hline $\mathrm{LDL}(\mathrm{mg} / \mathrm{dl})$ & $73.9 \pm 7.6^{\mathrm{a}}$ & $43.93 \pm 5.5^{\mathrm{b}}$ & $54.8 \pm 9.06^{\mathrm{ab}}$ \\
\hline VLDL (mg/dl) & $36.8 \pm 2.1^{\mathrm{a}}$ & $33.8 \pm 1.3^{\mathrm{a}}$ & $25.32 \pm 2.9^{b}$ \\
\hline Total protein $(\mathrm{g} / \mathrm{dl})$ & $8.6 \pm .83 \mathrm{ab}$ & $9.8 \pm .53^{\mathrm{a}}$ & $7.04 \pm .6^{\mathrm{b}}$ \\
\hline Globulin $(\mathrm{g} / \mathrm{dl})$ & $6.3 \pm .54 \mathrm{ab}$ & $7.25 \pm .33^{\mathrm{a}}$ & $5.12 \pm .41^{\mathrm{b}}$ \\
\hline Albumin (g/dl) & $2.3 \pm .27^{\mathrm{a}}$ & $2.58 \pm 0.14^{\mathrm{a}}$ & $1.92 \pm .23^{\mathrm{a}}$ \\
\hline AST (U/L) & $95.9 \pm 4.2^{\mathrm{b}}$ & $87.5 \pm 5.6^{\mathrm{b}}$ & $126.5 \pm 13.6^{\mathrm{a}}$ \\
\hline GGT (U/L) & $13.7 \pm 2.5^{\mathrm{b}}$ & $21.3 \pm 3.08^{\mathrm{ab}}$ & $34.62 \pm 7.8^{\mathrm{a}}$ \\
\hline $\operatorname{ALT}(\mathrm{U} / \mathrm{L})$ & $13.4 \pm .97^{\mathrm{b}}$ & $17.04 \pm .72 \mathrm{ab}$ & $19.8 \pm 2.2^{\mathrm{a}}$ \\
\hline Urea (mg/dl) & $96.3 \pm 4.5^{\mathrm{a}}$ & $81.4 \pm 2.7^{\mathrm{b}}$ & $74.6 \pm 1.9^{b}$ \\
\hline Creatinine (mg/dl) & $.6 \pm .11^{\mathrm{a}}$ & $.75 \pm .15^{\mathrm{a}}$ & $.87 \pm .13^{\mathrm{a}}$ \\
\hline $\mathrm{Ca}(\mathrm{mg} / \mathrm{dl})$ & $8.6 \pm .44^{\mathrm{a}}$ & $8.4 \pm .52^{\mathrm{a}}$ & $5.07 \pm .37^{\mathrm{b}}$ \\
\hline $\mathrm{P}(\mathrm{mg} / \mathrm{dl})$ & $5.6 \pm .45^{\mathrm{a}}$ & $4.8 \pm .24^{\mathrm{a}}$ & $3.46 \pm .27^{\mathrm{b}}$ \\
\hline $\operatorname{MDA}(\mathrm{nmol} / \mathrm{ml})$ & $2.7 \pm .6^{\mathrm{b}}$ & $3.2 \pm .2^{\mathrm{b}}$ & $5.9 \pm .3^{\mathrm{a}}$ \\
\hline $\mathrm{SOD}(\mathrm{U} / \mathrm{ml})$ & $44.8 \pm 9.4^{\mathrm{a}}$ & $30.8 \pm 3.2$ ab & $18.4 \pm 2.8^{\mathrm{b}}$ \\
\hline
\end{tabular}

Means with different superscripts indicate significant difference at $P<0.05$

\section{DISCUSSION}

Clinical examination showed anorexia (partial and complete anorexia) and scanty firm feces in CK cows. These clinical signs are similar to those previously observed in ketotic cows (İssi et al., 2016) and ketotic buffaloes (Bali et al., 2016). Decreased milk yield in SCK and CK cows is similar to previously recorded in cows (İssi et al., 2016) and in buffaloes (Youssef et al.., 2010). Hypoglycemia due to ketosis results in drop in lactose synthesis which leads to reduction in milk production (Lean et al., 1992). Moreover, elevated blood ketones also result in decreased milk production (Andersson and Lundstrom, 1985).
Detection of Acetone odor in breath of ketotic cows is similar to that observed in cattle (Ghanem et al., 2012 and Dar et al., 2014) and in buffaloes (Ghanem and El-Deeb, 2010). Although it is not a constant clinical signs of ketosis as acetone odor in breath was detected only in one CK cow in this study which was comparable to other study (Youssef et al., 2010).

The body temperature, respiratory rates and pulse rate of CK cows showed insignificant changes compared with SCK and control. These results are similar to what remarked by İssi et al. (2016). Moreover, several authors noted a non significant change in body temperature, respiratory rate and pulse rate in $\mathrm{CK}$ cows compared with 
control (Asrat et al., 2013 and Dar et al., 2014). The ruminal movements showed a significant decreased in CK cows compared with SCK and control. The ruminal stasis observed in ketotic cows is similar to that previously noted by Dar et al. (2014). Additionally, a significant decrease of ruminal movement in $\mathrm{CK}$ buffaloes compared with healthy buffaloes was previously remarked (Bali et al., 2016). Depressed ruminal motility could be attributed to excessive generation of ketone bodies. Ketones bodies are reported to affect ruminal motility causing incomplete and depressed ruminal contraction (Andersson and Lundstrom, 1985).

Regarding the biochemical analysis of serum, serum glucose levels showed a significant decrease in SCK and CK cows compared with control. This result in agreement with those previously recorded in ketotic cows by Sun et al. (2014). Moreover, Youssef et al. (2010) and Bali et al. (2016) recorded a significant decrease in serum glucose levels in CK buffaloes than healthy buffaloes. Decreased blood glucose levels are attributed to an increased mammary gland activity in lactose synthesis as well as to a reduced hepatocyte activity to synthesize glucose through gluconeogenesis under lipomobilization and lipogenesis in the liver (Đjoković et al., 2014). Decreased blood glucose levels may be attributed to intake of low energy diet (Bremmer et al., 2000), especially at the early stage of lactation when high rate of glucose utilization in the mammary gland is required (Nazifi et al., 2008). Serum NEFA levels showed a significant increase in SCK and $\mathrm{CK}$ cows compared with control. This result is in agreement with ( $\mathrm{Li}$ et al., 2016). NEFA concentration reflects the magnitude of fat mobilization from body reserves and reflects the energy and dry matter intake (Adewuyi et al., 2005). Blood concentration of NEFA considered as the best indicator of NEB and of the lipomobilization (Đjoković et al., 2016). The increase of NEFA could be attributed to an increase in lipolysis as a result of stimulation of hormonesensitive lipase in adipose tissue due to hypoinsulinemia (Lewis et al., 2002). Serum BHBA levels showed a significant increase in SCK and CK cows compared with control. This result in agreement with those previously recorded in ketotic cows by Li et al. (2016) and in CK and in SCK buffaloes by Youssef et al. (2010). Dairy cows experience a NEB because the drain of energy for milk production exceeds the energy uptake from the ingested feed stuffs. This imbalance leads to mobilization of body fat reserves in the form of fatty acids, this result in an increase in ketone body production in the liver (Zhang et al., 2009). Blood BHBA originates from the liver (due to incomplete oxidation of fatty acids) (Oetzel, 2007). Low dry matter intake and increased lactational demand for energy result in propionate deficiency which leads to a lack of oxaloacetate used to convert acetate, butyrate and NEFA to energy in the tricarboxylic acid cycle. As a result, the acetyl-coenzyme A synthesized from acetate, butyrate and NEFA cannot enter into the tricarboxylic acid cycle and is converted to ketone bodies (acetone, acetoacetate and BHBA) (Kara, 2009). NEFA and BHBA are products of fat catabolism that can supply energy to body. Their increased levels in blood are symbols of NEB, which predict a great amount of fat mobilization (Gonzales et al., 2011).

Serum insulin levels showed a significant decrease in SCK and CK cows compared with control. Decreased serum insulin in SCK is in agreement with those previously recorded in ketotic cows by Sadeghi et al. (2011). Low plasma insulin concentration reduces glucose uptake by non - mammary extra hepatic tissue and makes glucose available for up take by the mammary gland which is not responsive to insulin (Bauman, 2000). Decreased insulin concentrations also promote the release of NEFA by the adipose tissue through hormone-sensitive lipase (McGuire et al., 1995). Insufficient blood glucose levels induce a decline in plasma insulin, and mobilization of triacylglycerol deposits as NEFA (Block and Sanchez, 2000). Insulin is low in type I diabetes because of a pancreatic defect, but in type I ketosis insulin is low because of chronic hypoglycemia due to a shortage of glucose precursors (Oetzel, 2007).

Serum cortisol levels showed a significant decrease in SCK and CK cows compared with control. Decreased blood cortisol levels in ketotic cows are similar to those previously observed in ketotic cows (Forslund et al., 2010). Under low blood cortisol levels ketotic cows undergoing a NEB and increased lipomobilization from body reserves, the ability of liver cells to synthesize glucose from gluconeoplastic precursors is substantially decreased. The ketogenic and lipogenic processes in the liver are intensified, blood levels of NEFA and ketonic bodies increase, and hypoglycemia develops (DjoKovic et al., 2013). Lower blood cortisol levels were attributed to dysfunction of the hypothalamusadenohypophysis-adrenal cortex axis in dairy cows.

Serum TG levels showed a significant decrease in SCK and CK cows compared with control. A significant decreased serum TG levels in ketotic cows is in agreement with to those previously recorded in ketotic cows by Đoković et al. (2012). TG accumulates in the liver cells of ketotic cows 
and causes their blood values to decrease (Đjoković et al.,2016). Veenhuizen et al. (1991) attributed the decrease in TG in blood to significant increase of FFA concentrations in the blood causes an increase of the content of lipids in the liver cells (fatty liver). Serum cholesterol levels showed a significant decrease in SCK and CK cows compared with control. This result is in agreement with those previously recorded in ketotic cows by Li et al. (2016). Decreased Serum cholesterol levels could be attributed to mild liver steatosis which cause reduction in cholesterol formation in the liver (Grummer, 1995). Increased accumulation of TG and cholesterol in hepatocytes in the puerperal ketotic cows probably linked to a depleted liver synthesis of VLDL (Moore and Roberts, 1998). Serum HDL levels showed a significant decrease in SCK and CK cows compared with control. This result is in agreement with those previously recorded by $\mathrm{Li}$ et al. (2016). Farid et al. (2013) explained the decrease in serum HDL is a result of impaired hepatic secretion of apolipoprotein $\mathrm{A}$, the basic protein for the synthesis of HDL. Decreased serum HDL may also be related to the lower cholesterol levels seen in ketotic cows, as HDL consists of about $60 \%$ cholesterol (Rayssiguier et al., 1998). Decreased HDL may be attributed to depressed lipoprotein lipase (LPL) as there is a positive association between LPL and HDL (Cheung et al., 2003). Since LPL is insulin dependent, the depression of LPL activity may be due to hypoinsulinemia and insulin resistance (Herrera et al., 1990). Serum LDL levels showed no significant decrease in CK cows compared with control. SCK showed a significant decrease compared with control. Decreased serum LDL levels in ketotic cows are in agreement with Bali et al. (2016) in buffaloes. Miyamoto et al. (2006) attributed the reduction of serum LDL levels due to fatty liver. Moreover, Farid et al. (2013) explained the decrease in serum LDL as a result of decreased VLDL secretion and decreased conversion to LDL. The decreased LDL levels could be attributed to the increased rate of LDL catabolism (Spady et al., 1985). Serum VLDL levels showed a significant decrease in CK cows compared with SCK and control. Decreased VLDL level in CK cows compared with control is coincided with that previously recorded ( $\mathrm{Li}$ et al.,2016). Moreover, decreased synthesis and secretion of VLDL in the liver of ketotic cows was observed by Yamamoto et al. (2001). VLDL decreases in cows with fatty liver (Katoh, 2002). Low secretion of VLDL in ruminants indicates the development of ketosis (Kleppe et al., 1998).

Serum TP levels showed a significant decrease in CK cows compared with SCK and control.
Decreased serum TP levels in ketotic cows is in agreement with those previously recorded by $\mathrm{Xu}$ et al. (2014) who attributed this reduction to the abnormal status of liver function of ketotic cows. Serum globulin levels showed a significant decrease in CK cows compared with SCK. This result is in agreement with those previously recorded in ketotic cows by Gonzales et al. (2011) who found a negative correlation between serum BHBA and serum globulins. Serum albumin levels showed insignificant decrease in $\mathrm{CK}$ cows compared with control. This result is in agreement with those previously recorded in cows by Xu et al. (2014). Decreased liver synthesis of albumin is induced by the development of fatty liver infiltration (Lubojacka et al., 2005).

Regarding the enzymatic activities, the AST activity showed a significant increase in CK cows compared with SCK and control. This result is in agreement with those previously recorded in ketotic cows by Li et al. (2016). Moreover, Youssef et al. (2010) observed a significant increase in serum AST activities in CK buffaloes than SCK and healthy buffaloes. Although AST is nonspecific liver enzyme estimation of its activity in dairy cows is most often associated with fatty liver syndrome (Đjoković et al., 2016). Serum activities of AST are correlated with the degree of fatty infiltration in the liver (Đoković et al.,2012). Serum concentration of AST increases due to fat accumulation in the liver which results in high hepatocytes membrane permeability (Karasai and Schefar, 1984). Moreover, Stojević et al. (2005) found that higher concentrations of AST in dairy cattle are associated with fatty liver syndrome, lower dry matter intake and ketosis signs. GGT serum activities showed a significant increase in CK cows compared with control. This result is in agreement with those previously recorded in ketotic cows by Sahinduran et al.( 2010) and in ketotic buffaloes (Ghanem and El-Deeb , 2010). Liver is the main source of serum GGT (Kaneko, 1989). Steen et al. (1997) attributed the increase of serum GGT levels to liver and bile duct malfunctions. Fatty liver infiltration and the hepatocyte degeneration involve cell membrane damage and hepatocyte destruction coupled to the release of cytoplasm enzymes (GGT) (Lubojacka et al., 2005). Serum ALT showed a significant increase in CK compared with control. This result is in agreement with that was previously recorded in ketotic cows by Li et al. (2016). The significant increase of serum ALT activities in ketotic cows may indicate impaired hepatic function (hepatic lipidosis and/or disruption hepatobiliary circulation (Sahinduran et al., 2010). On the contrary, Stojević et al. (2005) considered that the 
role of ALT in predicting liver damage in ketosis is insignificant.

Regarding the kidney functions, serum urea levels showed a significant decrease in SCK and CK cows compared with control. This result is in agreement with that previously recorded in ketotic cows by Shin et al. (2015). Urea is indicators of hepatic functionality and decrease in its concentration may suggest fat infiltration into the liver (Gonzales et al., 2011). On the contrary, Elitok et al. (2010) observed that serum urea levels in ketotic cows were significantly higher compared with control and attributed that to possible liver damage. Creatinine serum levels showed no significant change in CK cows than SCK and control. This result is lined with that previously recorded in ketotic buffaloes (Bali et al., 2016). On the other hand, İssi et al. (2016) noted a significant increase in creatinine serum level in ketotic dairy cows than control and attributed that to partial damage of nephrons. So, we concluded that ketosis had no effect on the kidney in this study as there was a non-significant increase in serum creatinine in CK cows and SCK compared with control.

Regarding the serum mineral changes, $\mathrm{Ca}$ serum levels showed a significant decrease in CK cows compared with SCK and control. This result is coincided with those recorded in ketotic cows (Simonov and Vlizlo, 2015).

Decreased $\mathrm{Ca}$ levels can be attributed to increased loss of base in the urine to compensate for the acidosis reported in cows with ketosis (Radostits et al., 2007). Moreover, Walsh et al. (2007) attributed hypocalcemia in ketotic cows to disorders of vitamin D metabolism due to damage of organs, involved in its metabolism (liver). Serum P levels showed a significant decrease in CK cows compared with SCK and control, which is in agreement with those previously in buffaloes by Bali et al. (2016). Youssef et al. (2010) attributed the decrease in $\mathrm{P}$ levels to inadequate phosphorus supply in the diet, prolonged anorexia, and increased urinary phosphorus excretion due to hyperparathyroidism.

Regarding the oxidant-antioxidant activity, MDA serum levels showed a significant increase in CK cows compared with SCK and control. The significant increased MDA levels in CK cows compared with control is in agreement with those previously recorded in cows by $\mathrm{Li}$ et al. (2016). Moreover, Youssef et al. (2010) recorded a significant increase in MDA level in CK buffaloes than normal buffaloes. Additionally, $\mathrm{Xu}$ et al. (2014) recorded a significant increase in serum MDA levels in ketotic cows compared with control. A great amount of NEFAs from fat mobilization of dairy cows affected ketosis may produce a great deal of oxygen radical, such as ROS, which can initiate oxidative stress (Schönfeld and Wojtczak, 2008). MDA is a degradation product of lipid peroxidation after exposure to ROS and its level in blood may be considered as an assessing indicator of lipid peroxidation degree (Turk et al., 2008). SOD serum levels showed a significant decrease in CK cows compared with control. This result is in agreement with those previously recorded in ketotic cows by $\mathrm{Li}$ et al. (2016). Decreased SOD levels explained by the serious damage that occurred in the erythrocyte membrane and other cellular structures depending on inability to fully detoxify oxygen free radicals (Gurdoga et al., 2014). However, Xu et al. (2014) observed a significant increased SOD levels in ketotic cows due to enhanced antioxidative ability. Pedernera et al. (2010) concluded that imbalance in oxidants-antioxidants imbalance, an excess of oxidants and/or a depletion of antioxidants, can lead to oxidative stress which cause cellular damage. The oxidative damage could also be a contributing factor for damage of hepatic cells and release of hepatic enzymes that were observed in our study.

Ultrasonographic examination of normal liver showed a homogenous gray granular echotexture of parenchyma and clear distinction of vessels. Ultrasonographic examination of liver in ketotic cows revealed hyper- echogenicity (increased hepatic brightness with higher hepatic fat contents). As hepatic fat accumulation increased the liver appears more echogenic and brighter on the ultrasound screen and blurring of hepatic blood vessels (Braun, 2009). With increased liver fat content, beam attenuation and backscattering, fine echogenicity and vascular blurring increased, of which beam attenuation was the most prominent change at higher fat infiltration (Tharwat et al., 2012). High echogenicity of fat is due to its lower acoustic impedance in contrast with that of the normal liver tissue (Braun et al., 1996). Acorda et al. (1994) and Braun et al. (1996) attributed blurring of hepatic blood vessels to the swollen hepatic tissue that compressing the blood vessels and to the increase in the scattered echoes in the hyperechoic areas of the diseased liver, these echoes projected on the vessels resulting in deteriorating of the contrast between the hepatic parenchyma and hepatic vessels. Therefore, our results suggested the use of hepatic ultrasonography as a potential non-invasive supplementary tool for diagnosis of hepatic fatty infiltration in ketotic cows in conjunction with other biochemical markers.

\section{CONCLUSION}


Ketosis, either clinical or subclinical, is an important metabolic disorder in Holstein- Friesian dairy cows in Egypt which associated with reduction in milk yield, several biochemical changes and associated with increased oxidative stress markers which reflect the negative impact of ketosis on dairy cows. The hepatic ultrasonography could be used as a potential non-invasive method for diagnosis of fatty liver infiltration in ketotic cows in collaboration with other biochemical parameters

\section{REFERENCES}

Abuelo, A., Hernandez, J., Benedito, J.L., Castillo, C., 2013. Oxidative stress index (OSi) as a new tool to assess redox status in dairy cattle during the transition period. Animal 7, 1374-1378.

Acorda, J.A., Yamada, M.H., Ghamsari, S.M., 1994. Evaluation of fatty infiltration of the liver in dairy cattle through digital analysis of hepatic ultrasonograms. Veterinary radiology and ultrasound35, 120-123.

Adewuyi, A. A., Gruys, E., Van Eerdenburg, F.J.C.M., 2005. Non-esterified fatty acids (NEFA) in dairy cattle. A review. Vet Q 27, 117-126.

Andersson, L., Lundstrom, K., 1985. Effect of feeding silage with high butyric acid content on ketone body formation and milk yield in postparturient dairy cows. Zentralblatt fur Veterinarmedizin. Reihe A 32, 15-23.

Asrat, M., Tadesse, G.H., Gounder, R.V., Nagappan, R., 2013. Prevalence and Treatment of Ketosis in Dairy Cows in and Around Addis Ababa, Ethiopi. British Journal of Dairy Sciences 3, 2630.

Bali, G., Hussain, K., Razzaque, W.A.A., Sharma, U., Beigh, S.A., 2016. Clinico-biochemical studies of ketosis in buffalo (bubalus bubalis). Buffalo bulletin, 35 (1): 27-32. ketosis. Turk. J. Vet. Anim. Sci.40, 47-52.

Bauman, D.E., 2000. Regulation of nutrient partitioning during lactation: homeostasis and homeorhesis revisited, in: Cronje, P.J. (Ed.), Ruminant Physiology: Digestion, Metabolism and Growth and Reproduction, CAB Publishing, New York, Pp. 311-327.

Block, E. Sanchez, W., 2000. Special nutritional needs of the transition cow. Middle South Nutrition Conference, Dallas, TX.

Braun, U., 2009. Ultrasonography of the liver in cattle. The Veterinary clinics of North America. Food animal practice 25, 591-609.

Braun, U., Pusterla, N., Wild, K., 1996. Ultrasonographic examination of the fatty liver and gallbladder in cows: Abnormal findings. Compendium on Continuing Education for the Practicing Veterinarian18, 1255-1269.

Bremmer , D.R., Trower, S.L., Bertics, S.J., Besong, S.A., Bernabucci, U., Grummer, R.R., 2000. Etiology of fatty liver in dairy cattle: effects of nutritional and hormonal status on hepatic microsomal triglyceride transfer protein. Journal of dairy science $83,2239-2251$

Cheung , M.C., Sibley, S.D., Palmer, J.P., Oram, J.F., Brunzell, J.D., 2003. Lipoprotein lipase and hepatic lipase: their relationship with HDL subspecies Lp(A-I) and Lp(A-I,A-II). Journal of lipid research 44, 1552-1558.

Dar, K.H., Ansari, M.M., Tantary, H.A., Baba, M.A., Ashraf, I., 2014. Studies on Efficacy of Therapeutic Protocols for Ketosis in Dairy Cows. Inter J Vet Sci. 3, 147-150.

Đjoković, R., Ilić, Z., Kurćubić, V., Petrović, M.P., Petrović, V. C., Milošević, B., Omerović, I. , 2016 . Determination metabolic and nutritional status in dairy cows during early and midlactation. Biotechnology in Animal Husbandry $32,1-8$.

Đjoković, R., Cincović, M., Kurćubić, V., Petrović, M., Lalović, M., Jašović, B. ～， Stanimirovi, Z., 2014. Endocrine and Metabolic Status of Dairy Cows during Transition Period. Thai J Vet Med.44, 59-66.

DjoKovic, R., Kurčubić, V., Ilić, Z., Cincović, M., Petrović, M. ,Fratric , N. , jasovic ,B. ,2013. Evaluation of metabolic status in Simmental dairy cows during late pregnancy and early lactation. Veterinarski Arhiv83, 593-602.

Đoković, R., Šamanc, H., Petrović, M. D., Ilić, Z., Kurćubić, V., 2012. Relationship among blood metabolites and lipid content in the liver in transitional Dairy Cows. Biotechnology in Animal Husbandry28, 705-714.

Duffield, T., 2000. Subclinical ketosis in lactating dairy cattle. The Veterinary clinics of North America. Food animal practice 16, 231-253.

Elitok, B., Solak, M.; Kabu, M., Elitok, ÖM; Söylemez, Z., Fistık, T. , 2010. Clinical, haematological, serum biochemical and cytogenetic study in cows with primary ketosis. Pak. Vet.J. 30, 150154.

Farid , A.S., Honkawa, K., Fath, E.M., Nonaka , N., Horii, Y., 2013. Serum paraoxonase-1 as biomarker for improved diagnosis of fatty liver in dairy cows. BMC veterinary research 9, 73 .

Forslund, K.B., Ljungvall, O.A., Jones, B.V., 2010. Low cortisol levels in blood from dairy cows with ketosis :a field study. Acta veterinaria Scandinavica 52, 31.

Ghanem, M. M., El-Deeb W.M., 2010. Lecithin cholesterol acyltransferase (LCAT) activity as predictor for ketosis and parturient haemoglobinuria in Egyptian water buffaloes. Research in Veterinary Science 88, 20 -25.

Ghanem, M. M., Mahmoud, M. E., Abd El-Raof, Y. M., El-Attar, H. M., 2012. Metabolic profile test for monitoring the clinical, haematological and biochemical alterations in cattle during periparturient period. Banha Veterinary Medicine Journal 23, 13-23.

Gonzalez , F.D., Muino, R., Pereira, V., Campos, R., Benedito, J.L., 2011. Relationship among blood indicators of lipomobilization and hepatic 
function during early lactation in high-yielding dairy cows. Journal of veterinary science 12 , 251-255.

Grummer, R.R., 1995. Impact of changes in organic nutrient metabolism on developing feeding strategies to minimize stress during the transition from late pregnancy to early lactation. J Anim Sci.73, 2820-2833.

Gurdogan, F., Balıkçı, E., Yıldız, A., 2014. Some acute phase proteins, oxidative stress biomarkers and antioxidant enzyme activities in ewes with pregnancy toxemia. Iranian Journal of Veterinary Research, Shiraz University15, 297-299.

Herrera, E., Ramos, P, Martı'n, A., 1990. Control by insulin of adipose tissue lipoprotein lipase activity during late pregnancy in the rat. In Frontiers in Diabetes Research Lessons from Animal Diabetes III, E. Shafrir, Editor SmithGordon, London. vol XI:551-554.

İssi, M., Gul,Y., Başbuğ, O., 2016. Evaluation of renal and hepatic functions in cattle with subclinical and clinical ketosis. Turk J Vet Anim Sci. 40, 4752.

Kaneko, J.J., 1989. Clinical Biochemistry of Domestic Animals. 4th Edn., Academic Press, New York, California, USA., Pp: 898.

Kara, Ç., 2009. Süt sığırlarının geçiş dönemlerinde kalsiyum propiyonat katkısının süt verimi ve bileşimi ile ketozis, hipokalsemi ve bazı döl verimi parametrelerine etkileri. The Degree of Doctor of Philosophy Thesis, U. Ü. Veteriner Fakültesi, Bursa, Turkey.

Karasai, F., Schefar, M., 1984. Diagnostic experiences with metabolic liver diseases of dairy cows. Monta Fur Veterinar 39, 181-186.

Katoh, N., 2002. Relevance of apolipoproteins in the development of fatty liver and fatty liver-related peripartum diseases in dairy cows. The Journal of veterinary medical science / the Japanese Society of Veterinary Science 64, 293-307.

Kelly, W.R. ,1984. Veterinary Clinical Diagnosis, $3^{\text {rd }}$ ed., Bailliere ndall, London, U.K,

Kleppe, B.B., Aiello, R.J., Grummer, R.R., Armentano, L.E., 1988. Triglyceride accumulation and very low density lipoprotein secretion by rat and goat hepatocytes in vitro. Journal of dairy science 71 , 1813-1822.

Kohen, R., Nyska, A., 2002. Oxidation of biological systems: oxidative stress phenomena, antioxidants, redox reactions, and methods for their quantification. Toxicologic pathology 30 , 620-650.

Lean, I.J., Bruss, R.L., Baldwin, R.L., Troutt. H.F., 1992. Bovine ketosis: A review II. Biochemistry and prevention. Vet. Bull.62, 1-14.

Lewis, G.F., Carpentier, A., Adeli, K., Giacca, A., 2002. Disordered fat storage and mobilization in the pathogenesis of insulin resistance and type 2 diabetes. Endocrine reviews 23, 201-229.

Li, Y., Ding, H. Y., Wang, X. C., Feng, S. B., Li, X. B., Wang, Z., Liu, G. W., Li, X. W., 2016. An association between the level of oxidative stress and the concentrations of NEFA and BHBA in the plasma of ketotic dairy cows. Journal of Animal Physiology and Animal Nutrition. Article first published online: 14 APR 2016 DOI: $10.1111 /$ jpn. 12454

Lubojacka, V., Pechova, A., Dvorak, R., Drastich, P., Kummer, V., Poul, J., 2005. Liver steatosis following supplementation with fat in dairy cows' diets. Acta Veterinaria Brno74, 217-224.

McGuire, M.A., Griinari, J.M., Dwyer, D.A., Bauman, D.E., 1995. Role of insulin in the regulation of mammary synthesis of fat and protein. Journal of dairy science 78,816-824.

Miyamoto, T., Sugiyama, Y., Suzuki, J., Oohashi, T., Takahashi, Y., 2006. Determination of bovine serum low-density lipoprotein cholesterol using the $\mathrm{N}$-geneous method. Veterinary research communications 30, 467-474

Moore , K., Roberts, L.J., 2nd ,1998 . Measurement of lipid peroxidation. Free radical research 28,659 671.

Nazifi, S., Mhebbi Fani, M, Rowghani, E., Behlood, M.R., 2008.Studies on the relationship Between Sub-Clinical Ketosis and Liver Injuries Within the First Two Months of Lactation Period in High Producing Iranian Holstein cows: International Journal of Dairy Science3, 29-35.

Oetzel, G.R., 2007. Herd-level ketosis - diagnosis and risk factors. In: Pre-conference Seminar 7C: Dairy Herd Problem Investigation Strategies: Transition Cow Troubleshooting, 40th Annual Conference of the American Association of Bovine Practitioners, Vancouver, BC, Canada, Pp. 67-91.

Pedernera, M., Celi, P., Garcia, S.C., Salvin, H.E., Barchia, I., Fulkerson, W.J., 2010. Effect of diet, energy balance and milk production on oxidative stress in early-lactating dairy cows grazing pasture. Veterinary journal (London, England: 1997) $186,352-357$.

Radostits, O.M., Gay, C.C., Blood, D.C., Hinchdiff, K.W., 2007.Veterinary Medicine. A Textbook of the Diseases of Cattle, Sheep, Pigs, Goats and Horses 9th ed WB. Saunders, London. pp: 16611668.

Rayssiguier, Y., Mazur, A., Gueux, E., Reid, I.M., Roberts, C.J., 1988 Plasma lipoproteins and fatty liver in dairy cows. Research in veterinary science 45, 389-393.

Rosenberger, G., Rindes, KD., 2006. unveraenderte Auflage. Berlin, Germany: Blackwell Wissenschafts-Verlag; (in German).

Sadeghi , N. A. , Hassanpour, A., Sabaghsaray, H. , Amiri sadeghan, S.,2011. Assessment of thyroid hormones, insulin and magnesium in dairy cattle with subclinical ketosis Veterinary Clinical Pathology (Veterinary Journal Tabriz) 5, $1149-1159$.

Sahinduran, S., Sezer, K., Buyukoglu, T., Albay, M.K., Karakurum, M.C., 2010. Evaluation of some haematological and biochemical parameters before and after treatment in cows with ketosis 
and comparison of different treatment methods. J. Anim. Vet. Adv.9, 266-271.

Schönfeld , P. , Wojtczak, L., 2008. Fatty acids as modulators of the cellular production of reactive oxygen species. Free Radic Biol Med. 45, 23141.

Shin, E.K., Jeong, J.K., Choi, I.S., Kang, H.G., Hur, T.Y., Jung, Y.H., Kim, I.H., 2015. Relationships among ketosis, serum metabolites, body condition, and reproductive outcomes in dairy cows. Theriogenology 84, 252-260.

Simonov, M., Vlizlo, V., 2015.Some blood markers of the functional state of liver in dairy cows with clinical ketosis. Bulgarian Journal of Veterinary Medicine18, 74-82.

Spady, D.K., Turley, S.D., Dietschy, J.M., 1985. Rates of low density lipoprotein uptake and cholesterol synthesis are regulated independently in the liver. Journal of lipid research 26, 465-472.

Steen, A., Gronstol, H., Torjesen, P.A., 1997. Glucose and insulin responses to glucagon injection in dairy cows with ketosis and fatty liver. Zentralblatt fur Veterinarmedizin. Reihe A 44, 521-530.

Stojević, Z., Piršljin, J., Milinković-Tur, S., Zdelar-Tuk, M. ,Ljubić, B.B., 2005. Activities of AST, ALT and GGT in clinically healthy dairy cows during lactation and in the dry period. Vet Arh75, 6773.

Sun, L.W., Zhang, H.Y., Wu, L., Shu, S., Xia, C., Xu, C., Zheng, J.S., 2014. (1) H-Nuclear magnetic resonance-based plasma metabolic profiling of dairy cows with clinical and subclinical ketosis. Journal of dairy science 97, 1552-1562.

Tharwat , M., Oikawa, S. , Buczinski, S., 2012. Ultrasonographic prediction of content in dairy cows during the transition period. J Vet Sci and Technol, 3:1.

Turk, R., Juretic, D., Geres, D., Svetina, A., Turk, N., Flegar-Mestric, Z., 2008. Influence of oxidative stress and metabolic adaptation on PON1 activity and MDA level in transition dairy cows. Animal reproduction science 108, 98-106.

Veenhuizen, J.J., Drackley, J.K., Richard, M.J., Sanderson, T.P., Miller, L.D., Young Veenhuizen, J.W., 1991. Metabolic changes in blood and liver during development and early treatment of experimental fatty liver and ketosis in cows. Journal of dairy science 74, 4238- 4253.

Walsh, R.B., Walton, J.S., Kelton, D.F., LeBlanc, S.J., Leslie, K.E., Duffield, T.F., 2007. The effect of subclinical ketosis in early lactation on reproductive performance of postpartum dairy cows. Journal of dairy science 90, 2788-2796.

Xu, C., Shu, S., Xia, C., Wang, B., Zhang, H.Y., Jun, B., 2014.Investigation on the Relationship of Insulin Resistance and Ketosis in Dairy Cows. J. Veterinar Sci Technolo.5, 162.

Yamamoto , M., Nakagawa-Ueta, H., Katoh, N., Oikawa, S., 2001. Decreased concentration of serum apolipoprotein C-III in cows with fatty liver, ketosis, left displacement of the abomasum, milk fever and retained placenta. The Journal of veterinary medical science / the Japanese Society of Veterinary Science 63, 227-231.

Youssef, M.A., El-Khodery, S.A., El-deeb, W.M., Abou El-Amaiem, W.E., 2010. Ketosis in buffalo (Bubalus bubalis): clinical findings and the associated oxidative stress level. Tropical animal health and production 42, 1771-1777.

Zhang, Z., Liu, G., Li, X., Wang, Z., Kong, T., Zghan, N., Guo, C., 2009. $\beta$-Hydroxybutyrate, glucose, calcium, phosphorus and vitamin $\mathrm{c}$ concentrations in blood of dairy cows with subclinical ketosis during the early lactation. Bull Vet Inst Pulawy54, 71-74.

Zhang, Z., Liu, G., Wang, H., Li, X., Wang, Z., 2012a. Detection of subclinical ketosis in dairy cows. Pak Vet J. 32, 156-160. 